\title{
Islamic Communication Pattern of Judges in Dealing Conflict of Muslim Families in the Religious Court Medan
}

\author{
Maria Ulfa Batubara, Lahmuddin Lubis, Syukur Kholil \\ State Islamic University of North Sumatera (UINSU) \\ tgkdrsaiful@gmail.com
}

\begin{abstract}
This study deals with Islamic Communication Pattern of Judges in Dealing Conflict of Muslim Families in the Religious Court Medan. The research methods used in this study is qualitative research. The results shows that the most important thing from the judge's communication pattern, namely the pattern of two-way communication or feedback (Two way traffic communication), namely Communicators and Communities to exchange functions in carrying out their functions, Communicators in the first stage became communicants and at the next stage alternating function. The pattern of Islamic communication as a strategy carried out by the judge is the selection of words or language that is good and a subtle tone of voice between the judge as a mediator and a married couple, so that they can feel comfortable when in the mediation process. The mediator is patient so that the husband and wife feel comfortable and easier to communicate. By providing Islamic communication to advice couples in different characters, various problems and other family interventions can provide the best solution for couples who are in the process of divorce, the judge also tries to make the husband and wife change their mind to want to revoke the divorce lawsuit and refer back.
\end{abstract}

Keywords : Islamic Communication Pattern; Judge; Family.

\section{Introduction}

Communication is one part of the relationship between humans both individuals and groups in everyday life $^{1}$, from this understanding is clear that communication involves a number of people where one expresses something to other people, so who is involved in communication is the man himself.

This differentiation of communication patterns illustrates the division of roles and positions of each individual in a family. The pattern of family communication plays a role in receiving messages and feedback that occurs between family members. For example in the monopoly communication pattern, only one person has the right to make decisions in the family. This causes other family members not to have the right to voice opinions or take part in decision making, which results in family communication tend to be one-way communication only. Likewise in the planting and development of values instilled by the holder of power is absolutely followed by other family members because communication that takes place is only an instruction or instruction.

The family has a very big role in teaching, guiding, determining behavior, and forming a perspective on the values that apply in society. The family is like giving the values that are needed by the child through an appropriate communication pattern so that communication goes well, harmonious relationships are created, and the messages and values to be conveyed can be accepted and practiced properly.

\footnotetext{
${ }^{1}$ Effendy, Onong Uchjana. 2003. Ilmu Teori dan Filsafat Komunikasi. (Bandung: Citra Aditya Bakti .2003), P. 141
} 
In line with what was revealed by Degenova (2008), that there are 12 characteristics of successful marriages, where communication is the main characteristic in the creation of successful marriages. But each partner has its own way of communicating known as communication patterns.

Religious Courts as one of the implementation of judicial power has the main task of receiving, examining and judging and completing every case submitted to him in order to uphold the law and justice based on Pancasila for the implementation of the legal state of the Republic of Indonesia (articles 1 and 2 of Law No. 14/1970).

Judges as executors of power, receiving, examining and deciding have two tasks, namely judicial tasks which are the main tasks and non-judicial tasks which are additional tasks, but do not reduce the important value in life in society and the state.

The application of communication as a means to convey messages only, but developed into an important thing in managing relationships between humans. There are problems that are solved properly or family. There are also problems that are resolved through legal channels. Through the judiciary by involving judges and lawyers in its resolution. One of them is in solving a problem in mediating a divorce case, the judge uses a communication pattern as a solution to the divorce case so that both parties end peacefully.

The judge as mediator will prioritize using the right strategy when interacting with married couples who are undergoing a divorce process. In the process, a married couple who are undergoing a divorce process are also determined by the reason they decided to end their marriage at the legal table. So, for the judge the responsibility that must be carried out is being able to communicate effectively with married couples that can be done using Islamic communication patterns. Inevitably if communication must be done as well as possible in order to achieve the goal of communicators to the communicant.

The communication process is less of a concern by the communicator in this case is the judge as a mediator or communicant, namely a married couple in the process of delivering messages. Can not be denied if there is communication that is not good it will have an impact on the purpose of both the meaning of the message that might not be achieved. Primarily, in divorce cases, the mediation process by the judge as a mediator to a married couple. The peace sought by the mediator should be done by considering using interpersonal communication strategies right, so that the peace efforts by the judge are able to change the decision married couple for peace.

\subsection{Conflict Theory}

\section{Conceptual Framework}

The theory of social conflict emerged in the 18th and 19th centuries as a response to the birth of dual revolution, namely democratization and industrialization, so that the emergence of modern conflict sociology, in America in particular, was a follower, or the result of conflict reality in American society. The 1960s were in line with the tide of individual freedom in the West, but have actually developed since the 17 th Century.

In addition, the sociological theory of conflict is an alternative to the disaffection of the analysis of the structural functionalism of Talcott Parsons and Robert K. Merton, who assess society by understanding consensus and its integralism.

Conflicts have various kinds of elements including that conflict has negative and positive effects, conflict can focus on the content of the conversation or material issues but conflicts can also be related to the person of the culprit. Conflict has several forms or styles 
and conflicts are also determined by cultural factors. So that the discussion about conflict can be viewed from various aspects and the more interesting is to know the impact of the conflict and link it to the causes of conflict.

Own conflict cannot be avoided when someone is in touch with other people. Even conflict can occur with individuals without involving other people. Regarding the understanding of broad conflicts and well integrated De Vitto (2007) and Galvin and Brommel (1986) both provide a description of the stages of conflict occurring up to how to manage conflict. It is stated that conflict has several stages of the process, namely the initial condition stage, the stage of frustration and awareness, the active stage, the solution stage or no solution is reached, the follow-up stage and the resolution stage.

If it is associated with the factors that cause conflict in the family, Galvin and Broomel further elaborate that family conflict can be categorized into two, namely those that focus on fundamental issues or are less focused on basic issues. Central or basic issues such as religion, child ownership, religion and education. Whereas conflicts that do not focus on the main issues are matters related to daily activities such as the decision to take a vacation or the division of work tasks. Some types of conflicts related to the above issues can be resolved, some of which do not reach the completion stage.

The worst condition if the conflict does not reach the completion stage is the separation or ending relationship. In the view of some experts adhering to a framework that examines families, family conflict is generally seen as a threat as family stability. Unlike the conflict approach because it is considered as a natural, natural result of human interaction. Because of such a view, in family studies using this approach there is an emphasis on conflict management and allocation of power and resources in the family. Another assumption is that conflict in the family can have positive and negative consequences and if the conflict is suppressed, it can have a negative effect on family members. If conflict does not arise, it does not mean that happiness is guaranteed.

Conflicts occur within the family in the context of the efforts of family members to fight for scarce resources, namely things that are given value, such as money, attention, power and authority in playing certain roles. Family members can also negotiate or hold a bargaining process in achieving competing goals. Conflict interactions range from verbal interactions to physical ones. Problematic interactions occur if there are no such rules, or if the rules of the rules are not set consistently, or if those rules are only accepted by one party.

\subsection{Communication Patterns}

"The communication pattern is defined as the form or pattern of relations between two or more people in the process of sending and receiving the right way so that the message in question can be understood"

"The dimensions of communication patterns consist of two types, namely patterns that are oriented to concepts and patterns that are socially oriented that have different directions of direction" Tubbs and Moss say that "communication patterns or relationships can be characterized by: complementary or symmetrical. In complementary relationships one form of dominant behavior from one participant brings subservient and other behavior. In symmetry, the degree to which people interact on the basis of similarity. Domination meets domination or obedience to obedience ${ }^{2}$. "Here we begin to see how the interaction process creates a

\footnotetext{
${ }^{2}$ T Stewart L. Tubbs-Sylvia Moss. Human Communication.(Bandung : Remaja Rosda Karya. 2001) P.26
} 
system structure. How people respond to each other determines the type of relationship they have.

From the above understanding, a communication pattern is a form or pattern of relations between two or more people in the process of sending and receiving messages that are associated with two components, namely a picture or plan that includes steps in an activity with components that are an important part of the occurrence relations of communication between humans or groups and organizations.

\subsection{Islamic Communication}

Before we discuss more deeply, it would be better to know what communication is and what Islam is. Communication is a form of human interaction that influences each other influences one another, intentionally or unintentionally. Not limited to forms of communication using verbal language, but also in terms of facial expression, painting, art and technology.

Whereas Islam in language means submissive, obedient, and peaceful. Islam according to the term is the name of religion which Allah revealed to guide people to the right path and according to human nature. Islam is a religion of da'wah ${ }^{3}$ means religion which always encourages its followers to always actively carry out da'wah activities.

In Arabic Islamic communication is known as Al-Ittisal which comes from the root of the wasala word which means "convey" as found in the Qur'an SuratAl-Qasas verse 51:

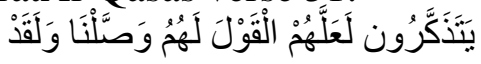

"And indeed we have sent down these words in succession (Al-Qur'an) to them so that they get a lesson". (Surah Al-Qashas: 51) Religious communication (religious communication) indeed includes Islamic communication but not the same as Islamic communication because religious communication encompasses all religions.

Even though Islam is different from other religions especially regarding its teachings. It is necessary to distinguish between Islamic communication and Islamic communication. Islamic communication is the communication system of Muslims. This means that, Islamic communication is more focused on the system with a philosophical background (theory) that is different from the perspective of non-Islamic communication. In other words the Islamic communication system is based on the Qur'an and the Hadist of the Prophet Muhammad. Whereas Islamic communication is the delivery process message between humans based on Islamic teachings. This means that Islamic communication is a way of communicating that is Islamic (not contrary to Islamic teachings). Thus finally convergence (meeting) occurs between the notion of Islamic communication and communication Islamic. It could be said, Islamic communication is the implementation (method of implementing) Islamic communication.

\subsection{Muslim Families (Husband and Wife)}

According to Islamic teachings forming an Islamic family is the happiness of the world of divinity is also one of the goals of family formation in Islam. Satisfaction and peace of mind will be reflected in a peaceful, peaceful, not turbulent family condition. This form of family is called the sakinah family. Such families will be created if in their daily lives all activities and behaviors that occur in them are colored and based on religious teachings.

It was further clarified by the Prophet (SAS) in his hadith that in a sakinah family there was a harmonious and balanced relationship between husband and wife, sexual desire was

\footnotetext{
${ }^{3}$ Masyhur Amin, Dakwah Islam dan Pesan Moral( Jakarta: Al-Amin Press, 1997), P. 8
} 
channeled well on the path blessed by Allah SWT, educated children who were pious and pious, fulfilled birth needs, spiritual needs , there is a close relationship between the extended family of the husband and from the wife's side, can carry out the teachings of religion well, can establish intimate relationships with neighbors, and can live in a good society and state as well. Like the hadith delivered by Anas ra. That when God wants a family to be an individual who understands and understands religion, the older ones love the smaller ones and vice versa, provide sufficient sustenance in their lives, achieve every desire, and avoid them from all trials, then a family is named sakinah, mawaddah, warahmah. ${ }^{4}$

The family is a basic family unit consisting of a husband, wife and children. ${ }^{5}$ Families in the Islamic view have a value that is not small. Even Islam pays great attention to family life by laying out wise rules to preserve family life from disharmony and destruction. Why is this so much the concern of Islam? Because it is undeniable that the family is the first brick to build a Muslim community palace and is a madrasa of faith that is expected to be able to produce generations of Muslims who are able to elevate Allah's sentence on earth.

If this foundation is strong in religion and morality, the community will be strong and the coveted security will be realized. On the contrary, if family ties and damage poison the members, then the impact will be seen in the community on how shocking and fragile forces cannot be obtained by security. ${ }^{6}$

Then, whenever there is a family or group or group of people consisting of two or more individuals, it cannot help, surely the presence of a leader or someone who has the authority to regulate and supervise other individuals (but does not mean the existence of superiors and subordinates) is needed.

Likewise with a family, because what is called a family is a minimum consisting of a husband and a wife who then appears to have children or children and so on. So, it should be necessary in a family to have a family leader whose job is to guide and direct and fulfill the needs of both the needs of the nature and the inner nature of the household in order to form a sakinah family, mawaddah wa rahmah.

\subsection{Religious Courts}

The Religious Court is a court that has the authority to handle civil cases that are put on by the community regarding issues that can be resolved by the Religious Courts. The Religious Courts are divided into 2 (two), namely: the Religious Court, and the Religious High Court. The Religious Courts or the first level courts are in the Regency and Municipality area, while the Higher Religion Courts or the last appeal / level Courts are in the area of the province.

Religious Courts is a court for people who are Muslim, article 1 point 1 Law No. 50 of 2009 concerning the Second Amendment to Law No. 7 of 1989 concerning the Religious Courts). The Religious Courts carry out judicial powers for people who are Muslim regarding certain cases. According to article 49 of Law No. 3 of 2006 concerning Amendments to Law No. 7 of 1989 concerning the Religious Courts ("Law 3/2006"), which is the authority of the religious court is the case in the first level between people who are Muslim in the field: Marriage, inheritance, will, grant, endowment, zakat, infaq, sadaqah, and sharia economy. In

\footnotetext{
${ }^{4} J a i l a n i, A d e . k o n s e p ~ k e l u a r a g a$ Menurut Islam(http://adejailani.blogspot.co.id/2012/02/konsep-keluarga-menurulislam.html)

${ }^{5} \mathrm{http} / / /$ cbdotnet.blogspot.com/2009/02/pandangan-kaluarga-menurut-islam.html

${ }^{6} \mathrm{http} / / /$ blog.re.or.id/keluarga-dalam-pandangan-islam.html
} 
accordance with the explanation of article 49 of Law 3/2006, what is meant by "among people who are Muslim" in article 49 is including a person or legal entity which naturally submits itself voluntarily to Islamic law concerning matters that are the authority of the Religious Courts.

The meaning of the Religious Courts as the first level court is a court that acts to receive, examine, and decide on any application or claim at the earliest and lowest stage. Agma's court acts as a daily court that accommodates at an early stage and decides or adjudicates all cases raised by justice seekers. Cannot submit a request or claim directly to the Religious High Court. All types of cases must first go through the Religious Courts in the position of hierarchy as the first court. For all petition or lawsuit filed to him in deciding it, it is forbidden to refuse to accept, examine, and decide the case submitted to him under any pretext. This is affirmed in article 56 which reads: "The court may not refuse to examine and decide on a case that is filed under the pretext that the law is not or unclear, but is obliged to examine and decide." acts as a gateway for receiving, examining and terminating each case. Cases that are not first submitted to the Religious Courts will never be resolved. It may not be immediately submitted to a higher court, namely the High Court. Because the function of the judiciary is given by the Law to the High Court not as the first court, but the appellate court.

\subsection{Marriage}

Marriage according to Nowan, is an expression of faith, that is, there is a union of two different bodies and individuals, in which a person places the meaning and happiness of his life in someone else.

According to Blood (1969), marriage itself is a unitary role of elements that are bound to interact with each other and influence each other. If one experiences obstacles or does not carry out its role there will be inequality so that sometimes other elements must replace to carry out this role. If the wife is sick, sometimes the husband must replace him with child care, washing dishes, and so on. When a husband and wife vow to get married, it means that each of them binds themselves to a spouse. Freedom as an individual is sacrificed, marriage is not an end point, but a long journey to achieve a mutually agreed goal. Each partner must learn about life together and must prepare mentally to receive strengths as well as lack of partners with good self-control.

Husband and wife are two people who are different in almost all their characteristics. The different characteristics ushered in are difficult to unite unless there is self-awareness to understand each other. One of the incompatibilities in the family, especially the husband and wife, is caused by differences of opinion that trigger conflict.

\section{Research Methods}

The research approach used in this study is qualitative research. Bogdan and Taylor define qualitative methodology as a research procedure that produces descriptive data in the form of written or oral words from people and observable behavior. This approach is directed at the background of the individual holistically (intact). So in this case it is not permissible to isolate individuals or organizations into variabael or hypotheses, but need to view them as part of a whole.

According to Nasution, qualitative research is observing people in the environment, interacting with them and interpreting opinions in the environment, interacting with them and 
interpreting their opinions about the world around them, then nana Syaodih Sukmadinatam stated that qualitative research is a study aimed at describing and analyze phenomena, events, social activities, attitudes, beliefs, perspectives, people's thoughts individually or in groups.

This qualitative research is specifically directed towards the use of case study methods. As Lincoln and Guba argued that the qualitative approach can also be called a case study or a qualitative study, namely in-depth and detailed research on everything related to the subject of research. Furthermore, Sayaekti Pujosuwarno ${ }^{7}$ expressed his opinion from Moh. Surya and Djumhur who stated that case studies can be interpreted as a technique of studying someone individually in depth to help him get a good adjustment.

\section{Disscusion}

Basically all problems will be solved by communication in terms of the communication pattern that is built must be two-way so as to bridge dispute resolution. Justice seekers must explain the laws and regulations in the country as well as divorce cases because it involves conveying the rights and obligations of husband and wife, after the rules are explained. The Defendant wants to understand the rules so that he is able to arouse the heart of the Plaintiff as a wife and finally is willing to revoke his case considering the subject matter is divorce, that there are so many benefits of mediation for justice seekers because of time efficiency and also the ability to resolve disputes peacefully.

The efforts of judges in mediating families who will divorce in the Medan Religious Court are one of the steps taken by the judge in an effort to minimize divorce cases that are rampant in the city of Medan.

The judge's communication strategy in the trial is not carried out optimally because as a communicator must be able to make communication strategies first so that the message delivered can reach the desired communication target.

The communication strategy in essence is planning (planning) and management (management) to achieve the goal. Communication strategy is concrete stages in a series of communication activities based on technical units for implementing communication objectives, while the technique is a choice of certain communication actions based on a predetermined strategy.

Thus, the communication strategy is the whole planning, tactics and methods used to facilitate communication by paying attention to all aspects that exist in the communication process to achieve the desired goals.

Communication strategy is needed by thinking by taking into account the supporting and inhibiting factors. It would be better if in communication strategies note the components of communication and supporting or inhibiting factors in each component, including the framework factor reference, factor of situation and condition, choice of communication media, purpose of communication message, and role of communicator in communication.

The communication patterns that must be taken into account by judges ${ }^{8}$ such as good communication rarely just happen. Too often people start talking or writing without thinking, planning, and stating the purpose of the message first. In fact, selecting the most appropriate channel, and choosing the right time to improve understanding and reduce resistance to

\footnotetext{
${ }^{7}$ Pujosuwarno, Sayekti.Studi kausu bahan Kuliah Studi kasus Untuk Satu Semester. (Yogyakarta IKIP.1986).P.1

${ }^{8}$ Hutauruk, Gunawan, Manajemen 2. Jakarta: Erlangga. 1989.P. 182
} 
change. With the existence of unclear assumptions although very important, but what often happens is ignored are the assumptions underlying the message that is not communicated.

The communication pattern of judges as mediators with married couples in the mediation of divorce cases, made efforts made by the judge as a mediator to the married couple in the Medan Religious Court in order to maintain the integrity of their household in accordance with the plans and procedures made by the judge as the mediator himself by looking at the condition, situation and background of the husband and wife who will be mediated.

Efforts made by judges as mediators to couples in mediating divorce cases aim to reduce divorce rates and resolve problems experienced by couples and to reconcile them. The efforts carried out by the judge as a mediator even gave the two sides more than one mediation which in general and mediators used the approach more personally, in order to maintain their household and achieve peace between the two. The mediator also provides guidance and provides solutions by using good words, being friendly, understanding what the husband and wife want because basically there are no problems that cannot be resolved so they want to change their decision to divorce.

According to Medan Religious Court data, the divorce rate in this region is classified as very high, divorce rates are between 120-160 cases, during January-October 2017 there were 1458 cases.

The divorce case was dominated by wife's lawsuit, while the trigger for divorce was dominated by the top three positions which were disharmony, domestic violence (domestic violence) and economic factors. Although many initially considered the jealous factor because of the recent social media not being the main source of family conflict low rating.

The divorce starts from the wife or the woman as the plaintiff, usually because the husband is not responsible, leaving the wife without giving birth and other things. Whereas the divorce case from the male as the plaintiff occurred usually on the grounds that the wife did not respect her husband until there was a third party in the marriage. ${ }^{9}$

The judge's judgment based on the facts of the trial became the entrance to psychologically looking at the issue of child custody. Judges can assess and measure the psychological proximity of parents to children / vice versa to be taken into consideration. In the days of the Caliph Sayyidina Ali ibn Abu Talib, there have been cases of seizure of postdivorce child custody. Because both parents both insisted on controlling the child, Sayyidina Ali ordered that the father cut off his son's body and divide it in half. One part for father and one for mother.

The requirement that judges simply understand the psychological development of children, will give birth to a partial and fair judgment. Legal justice for children must first consider the extent to which the ability of parents to exemplify the character development of children. Even though Article 105 (a) Compilation of Islamic Law (KHI) states that the maintenance of children who are not yet mumayyiz or 12 years old is the right of their mother, but the judge can exercise discretion that a mother is not always the holder of custody of children. If the facts of the trial reveal that the mother is a drunkard, gambler, likes to beat, often abandons children or is incapable of caring for children, it could be that custody is left to the father's side.

\footnotetext{
${ }^{9}$ Interviewed by mediator Mrs. Hj. Erma Sujati, SH, MH.14 November 2017.
} 
Islamic communication carried out in mediation is usually returned to the Compilation of Islamic Law regarding the obligations of husbands and wives they are not aware of, as the cleric said, husbands and wives must pray and be patient for household harmony, perhaps praying is not done so why do not divorced, which is not hard why divorce can be advised.

The judge had difficulty in giving advice in the trial in the form of direction that was not acceptable to the parties who had litigation who had a low educational background. In terms of communicating to the judge when conducting the trial. So the judge tried to understand the liturgical educational background, using communication that was easily understood by both parties in the trial.

The results of the examination of an agreement for peace or no agreement can be directly used as a basis by the panel of judges to carry out further legal proceedings: the making of a peace certificate or case examination according to the request or claim. Persuasion is an attempt to change individual attitudes by entering new ideas, thoughts, opinions and even facts through communicative messages.

The message that was conveyed intentionally was intended to create contradictions and inconsistencies between the components of individual attitudes and among the perpetrators' attitudes so as to disrupt the stability of the opportunity to make changes change. Just as happened in the Medan Religious Court, in the mediation process the mediators used persuasive communication to the parties in mediation with the aim of changing attitudes as desired by the mediator without their being aware and there is no element of coercion.

To enhance marital quality and realize sakinah family according to Islamic teachings, the task of BP 4 (Advisory Board, Guidance and Preservation of Marriage) also plays a role in overcoming marital shocks such as providing guidance, counseling, counseling, and consultation / counseling, regarding marriage, divorce, divorce, referral to the community both individuals and groups, directly or through mass media and electronic media.

The use of appropriate communication patterns carried out by judges is something that can make Muslim families who do marriages survive the marriage life. That communication patterns are the things that greatly influence the occurrence of harmony in their married life. The results also show that the most important thing from the judge's communication pattern, namely the pattern of two-way communication or feedback (Two way traffic communication), namely Communicators and Communities to exchange functions in carrying out their functions, Communicators in the first stage become communicants and at the next stage interchangeable functions. But in essence the initiating conversation is the main communicator, the main communicator has a specific goal through the Communication process, the process is dialogic, and feedback occurs directly. Some respondents answered the need for dialogical conversation, namely discussion, exchange of ideas, discussion, following changes in life outside the family and realizing the importance of effective family communication. Effective family communication occurs when there is no rigidity and formality in the family. So that between family members can communicate from the heart to the heart in a dialogic manner in various conditions and situations with ease and full of openness and familiarity.

\section{Conclusion}

The pattern of Islamic communication as a strategy carried out by the judge is the selection of words or language that is good and a subtle tone of voice between the judge as a 
mediator and a married couple, so that they can feel comfortable when in the mediation process. The mediator is patient so that the husband and wife feel comfortable and easier to communicate. By providing Islamic communication by advising married couples of different characters, various problems and other family interventions. Can provide the best solution for couples who are in the process of divorce, the judge also tries to make the husband and wife change their mind to want to revoke the divorce lawsuit and refer back.

\section{A. Books}

\section{References}

Al-Shâbûni, Muhammad _Ali, al-Tibyân fi ,Ulûm al-Qur"ân, Jakarta: Dinamika

Berkah Utama, 1985

Al-Shâbûni, Muhammad _Ali, al-Tibyân fi „Ulûm al-Qur"ân, Jakarta: Dinamika

Berkah Utama, 1985

Andi Abdul Muis, 2001,Komunikasi Islam ,Bandung: Remaja Rosdakarya,

Arief Budiman.1981. Pembagian Kerja secara seksual : Sebuah Pembahasan Sosiologis

Tentang Peran Wanita di Masyarakat. Jakarta : Gramedia.

Beebe, Steven A., Susan J. Beebe, Mark V. Redmond. Interpersonal Communication:

Relating to Others. Boston: Allyn and Bacon.1996

Burhan Bungin, 2001, Metodologi Penelitian Sosial, Surabaya. Airlangga University Press,

------. 2003. Analisis Data Penelitian Kualitatif, Jakarta: PT Raja Grafindo Persada

Coleman , J.C. and Hammen,C.L. 1974, Contemporary Psychology and Effective Behavior. Glenview: Scott Foresman and Co.

Cottle, Simon. 2003. News, Public Relations and Power, Sage Publications.London.

Dani Fardiansyah, 2004,Pengantar Ilmu Komunikasi, Ghalia Indonesia:Bogor,

Dagun. 1990. Maskulin dan Feminim. Jakarta: Rineka Cipta

Deddy Mulyana, 2008, Metodologi Penelitian Kualitatif, Paradigma Baru Ilmu Komunikasi

Dan Ilmu Sosial Lainnya, Bandung : PT. Remaja Rosdakarya,

Departemen Agam RI, 1986. Pedoman Pelaksanaan Pendidikan Agama Islam, Jakarta

Departemen Agama RI, 2001. Kompilasi Hukum Islam di Indonesia.Jakarta

DEPAG RI, Al-Quran dan Terjemahnya, Al-Hikmah, Dipenogoro, Bandung, 2008

Devito, Joseph. 1997, Komunikasi Antar Manusia. Jakarta. Profesional Books,

DeVito, Joseph A. 2007, The Interpersonal Communication Book .edisi 11. Pearson Educations, Inc.

Duck, S. W. 1982, Personal Relationships 4: Dissolving Personal Relationships, London and New York: Academic Press,

Djamarah, Bahri, Syaiful.2004. Pola Komunikasi Orang Tua dan Anak dalam Keluarga. Jakarta : PT. Reneka Cipta

Dawn M. Baskerville, May 1993. How DoYou Manage Conflict?. BlackEnterprise.

Effendy, Onong Uchjana; Kamus Komunikasi; Mandar Maju; Bandung; 1989.

Effendy, Onong Uchjana. 2003. Ilmu Teori dan Filsafat Komunikasi. Bandung: Citra Aditya Bakti

Eric Berner, 1964. Games People Play.Brought Games and Transactional Analysis to mainstream American and later the entire world.

Fajar, Marhaeni, 2009, Ilmu Komunikasi Teori \& Praktek, First Edition, Graha Ilmu, Yogyakarta, 
Fisher, Simon, dkk. 2001. Mengelola Konflik: Ketrampilan \& Strategi Untuk Bertindak. The British Council. Jakarta

Galvin, Sistematic Theology, vol.1, Minneapolis: Fortress Press,1991

Gamble, 2005. Teri Kwal, \& Gamble, Michael W. Interpersonal Communication in theory, practice, and context. Boston: Houghton Mifflin Company

Gunarsa, S.D., and Gunarsa, Y.S.D. 1985. Psikologi Perkembangan Anak dan Remaja, Cet. 2. Jakarta: Penerbit PT. Multindo Auto Finance. BPK.Gunung Mulia.

Haffied Cangara, 1998, Pengantar Ilmu Komunikasi,Jakarta: Raja Grafindo Persada,

Hadisubrata, Mengembangkan Kepribadian Anak Balita. Jakarta BPKGM.1990

Halim, Mahyudin , Komunikasi Islam. Bandung. Pustaka. 1985

Hutauruk, Gunawan. Manajemen 2. Jakarta: Erlangga. 1989

Ihromi, T.O, Berbagai Kerangka Konseptual dalam Pengkajian Keluarga, Bunga Rampai Sosiologi Keluarga. Yayasan Obor Indonesia, Jakarta.2004

Iman Suprayogo and Tabrani, 2001, Metodologi Sosial Agama, Bandung: PT Remaja Rosdakarya

Janu, Murdiatmoko, 2007, Sosiologi: Memahami dan Mengkaji Masyarakat, Jakarta, Grafindo Media Pratama

Kholil, Syukur, 2007. Komunikasi Islam, Bandung.Cipta Pustaka.

Laswell, E and Laswell, F. 1987. Marriage and The Family. 2nd ed. California: Wadsworth Publishing.

Lestari, Sri, 2012. Psikologi Keluarga. Jakarta: Kencana Prenada Media Group.

Liliweri, Alo. 1997. Komunikasi Antarpribadi. Bandung : Citra Aditya Bakti.

Liwidjaja, K., Kuntaraf, \& Kuntaraf, J. 2003. Komunikasi keluarga. Bandung. Indonesia Publishing House

Karim, Adiwarman. 2006. Bank Islam-Analisis Fiqih dan Keuangan. Jakarta : PT. Raja Grafindo Persada

Kriyantono, Rachmat. 2009, Teknik Praktis Riset Komunikasi . Jakarta: Kencana.

Masyhur Amin, 1997, Dakwah Islam dan Pesan Moral Jakarta: Al-Amin Press,

Mafri Amir,1999.Etika Komunikasi Massa Dalam Pandangan Islam. Jakarta: Logos.

Macquarrie, John, Martin Heidegger, Four Phenomenological Philosophers Husserl,1995, London: Lutterworth Press,

Mulyana, Deddy.2004. Metodelogi Penelitian Kualitatif.Bandung, PT Remaja Rosda Karya

Munandar Soelaeman, 1992. Ilmu Sosial Dasar Teori dan Konsep Ilmu Sosial, Bandung, PT. Eresco

Moleong, L.J. 2006, Metodologi Penelitian Kualitatif, PT. Remaja Rosdakarya. Bandung,

Milles, Mattew B., and A. Michael Huberman. 2007. Analisis Data Kualitatif. Universitas Indonesia.

Minnery, John R. Conflict 1980, Management in Urban Planning, Gower Publishing Company Limited, England.

M.Kamil Kozan. 2002. Subcultures and Conflict Management Style. Management International Review.

Munir, 2009, Metode Dakwah ,Jakarta: Kencana,

M, Nazir, 2005Metode Penelitian, Bogor, Ghalia Indonesia

Muhammad Hasbi Ash-Shiddieqy, Peradilan Dan Hukum Acara Islam .Semarang : Pustaka Rizki Putra, 1997 
Nana Syaodih Sukmadinata. 2005 Metode Penelitian Pendidikan.Bandung. Remaja Rosda Karya

Nasution, S. 2003. Metode Research, Jakarta. PT. Bumi Aksara

Nasy'at Al-Masri, Uklhti Al Muslimah Kaifa Tastaqbilin Mauludiki Al-Jadid, diterjemahkan H. Salim Basyarahil ,1994, dengan judul : Menyambut Kedatangan Bayi, Jakarta: Gema Insani Press.

Nawawi, H. 1995, Metode Penelitian Bidang Sosial. Yogyakarta : Gajah Mada University Press.

Nowan, 2007. Jomblo Asik Gila.Jakarta : PT Gramedia

Onong Uchjana Effendy, 2007, Ilmu Komunikasi Teori dan Praktek, Bandung : Rosdakarya,

Papalia, old. 2001, Perkembangan Pada Remaja. Jakarta : Rineka Cipta.

Parwito. 2007, Penelitian komunikasi kualitatif. Yogyakarta: PT LKiS Pelangi Aksara,

Parrot, Les \& Parrot, Leslie. 1999, Seputar Problema Suami Istri.(Jakarta: PT. Pustaka Delapratasa,

Poerwandari, E. Kristi. 1998. Metode Penelitian Sosial. Jakarta. Universitas Terbuka

Rakhmat, Djalaludin. 2004, Metode Penelitian Komunikasi. Bandung : Remaja Rosdakarya,

Rakhmat, 2005.Psikologi Komunikasi. Remaja Rosdakarya.Bandung

Riswandi, 2009, Ilmu komunikasi. Jakarta : Graha Ilmu,

Ross, Joel E. 1993. Total Quality Management: Text, Cases and Readings, London: Kogan Page Limited

Safron, 1979 and Hill et al., 1976 dalam Guerero dan Andersen dan Afifi, 2007

Sadarjoen.S.S. 2005. Konflik Marital.(Pemahaman Konsep, Aktual dan Alternatif Solusinya). Bandung . Refika Aditama

Sabiq, Sayid, Aqidah Islam, terjemahan, Moh, Abdil Rathomy, Bandung,Diponegoro, 1985

Sayekti Pujosuwarno.1994.Bimbingan dan Konseling Keluarga. Yogyakarta:Menara Mas Offset.

Sillars et al, Konflik dalam Kelurga, 016.http://diglib.uinsby.ac..id/3453/4Bab\%203.pdf

Soenarto, Pengantar Manajemen Pemasaran. First Edition. (Yogyakarta:Ust Press. 2006

Sugiyono, 2010, Metodelogi Penelitian Kualitatif, Kualitatif dan R\&D,Bandung Alfabeta Indonesia

Suharimi Arikunto, 2006, Prosedur Penelitian Suatu Pendekatan Praktek, Jakarta: PT. Rineka Cipta

Siahaan, S.M.Komunikasi Pemahaman dan Penerapan.Jakarta.BPK ,Gunung Mulia.1991

Singgih D Gunarsa. 2004. Psikologi Perkembangan Anak dan Remaja. PT BPK Gunung Mulia.Jakarta

Stewart L. Tubbs dan Sylvya Moss, 2006. Human Communication Konteks-Konteks Komunikasi, Bandung. Penerbit PT. Rosda Karya

Soejanto, 2001.Psikologi Komunikasi,Remaja Rosdakarya. Bandung.

Soenarto.2006. Pengantar Manajemen Pemasaran:Ust Press

Sunarto, Keluarga permata Hatiku, 2006. Jakarta, Jagadnita Publishing

Suryomentaram.2004.Kepribadan Sehat Menurut Konsep. Surakarta . Muhammadiyah Unversity Press

Sugiyono, 2008, Metode Penelitian Kuantitaif dan Kualitatif dan $R$ \& D, Bandung: CV. Alfabet,

Taufik, Anggun Nur. 2004. "Etika dalam Pandangan Muhammad Iqbal dan Immanuel Kant" Thesis, IAIN Sunan Ampel, Surabaya 
Tim Dosen PIF-Malang, 1988.Pengantar Dasar-Dasar Kependidikan, (Surabaya-Indonesia: Usaha Nasional

T Stewart L. Tubbs-Sylvia Moss. 2001, Human Communication. Bandung : Remaja Rosda Karya.

Vuchinich, S. (1992). Parenting, Peers and The Stability of Antisocial Behaviour in Preadolescent Boys. Developmental Psychology, 28, 510-521.

Wahyu, 1986. Ilmu Sosial Dasar, Surabaya: Usaha Nasional

Wahyu,2010.Pokok-pokok Materi Kuliah Sosiologi Pendidikan Islam, Banjarmasin

William J.Goode, 2004. Sosiologi Keluarga. (Jakarta: Edisi Pertama Bumi Aksara)

Wallace, A. Ruth and Alison, Wolf. 1986. Contemporary Sosciological Theory, The Continuing Classical Tradition. New Jersey: Prentice Hall, Inc. Englewood Cliffs

Walgito, Bimo. Bimbingan dan Konseling Perkawinan. Yogyakarta: Andi Offset.2004

West, Richard. Lynn H.Turner. "Pengantar Teori Komunikasi". Jakarta. Salemba Humanika.2007

White, J.M., \& Klein, D.M. 2002. Family Theories. Second Ed. Thousand Oaks:Sage Pub, Inc.

Qaimi, Ali. 2009. Pernikahan Masalah \& Solusinya. Jakarta: Cahaya

HR. Tirmizi, abu Dawud, Bukhari, Ahmad

HR. Muslim

HR. Al-Imam As-Sa'

Yusuf, M. P. 1990. Komunikasi dan Komunikasi Intruksional . Bandung. PT.Remaja Rosda Karya

\section{B. Thesis}

Indah DwiI Retno AstutiI,Pola Komunikasi Dan Manajemen Konflik Pada Pasangan Sama-Sama Bekerja (Studi Deskriptif Kualitatif Pola Komunikasi dan Manajemen Konflik Keuangan), tesis, eprints. upnjatim. ac.id/2012

Kholifah, Kholifah (2012) KomunikasiI Interpersonal Dalam Penyelesaian Konflik Suami Istri : Studi Kasus Konflik Rumah Tangga Di Kelurahan Dupak Kecamatan Krembangan Surabaya Tahun 2012. Undergraduate thesis, UIN Sunan Ampel Surabaya.http://digilib.uinsby.ac.id

Bayu Putra, Pola Komunikasi Serta Manajemen Konflik keluarga Penghuni kamar Kost ( Skripsi, Ilmu Komunikasi, Universitas Airlangga,2010)

Kholifah, KomunikasiI Interpersonal Dalam Penyelesaian Konflik Suami Istri (Studi Kasus Konflik Rumah Tangga Di Kelurahan Dupak Kecamatan Krembangan Surabaya Tahun 2012), http://digilib.uinsby.ac.id,

\section{Journals}

Damayanti Wardyaningrum, Komunikasi Untuk Penyelesaian Konflik dalam Keluarga : Orientasi Percakapan dan Orientasi Kepatuhan.( Jurnal Al-Azhar Indonesia seri pranata sosial, vol. 2, no. 1, maret 2013)

Dewi Anisa Wijayati, Subagyo ,Sri Herwindya Baskara, Pola Komunikasi Dalam Mempertahankan Hubungan perkawainan (Studi Deskriptif Kualitatif tentang Pola Komunikasi dalam Mempertahankan Hubungan Perkawinan pada Pasangan yang Menikah Muda di Desa Cikedunglor Kecamatan Cikedung Kabupaten Indramayu, (Jurnal Komunikasi Massa, Universitas Sebelas Maret, 2014) 


\section{Webs}

http://abdulsyahid-forum .blogspot.co.id/2009/03penyajian -data-statistik.htm

http://ade-jailani.blogspot.co.id/2012/02/konsep-keluarga-menurul-islam.htm/ Jailani, Ade.

konsep keluarga Menurut Islam

http://budiwicaksono.wordpress.com/tag/its/

http://cyberions.blogspot.com/2009/01/pola-komunikasi-antar-pribadiJenis komunikasi dibagi tugas.html.

http://damanikblok.blogspot.com/2011/10/pengertian-dan-ruang-lingkup-komunikasi.html/

Damanik, Pengertian dan Ruang Lingkup Komunikasi Islam

http://digilib.uinsby.ac.id/9691/2/bab\%201.pdf

http://digilib.uinsby.ac.id/9723/3/bab\%202.pdf

http://eprints.upnjatim.ac.id/5104/1/file1.pdf

http://female.kompas.com/read/2010/01/23/09432140/usia pernikahan rentan masalah

http://grahita.wordpress.com/2010/03/04/5-faktor-penyebab-terjadinya-konflik-antara- suamiistri

http://haryadikpi3b.blogspot.co.id/2015/08/bentuk-bentuk-komunikasi-islam.html

http://Jalmilaip.Wordpress.Com/2012/03/14/Pengertian-Agama-Islam/ Amiruddin ,Pengertian Agama Islam

http://members.tripod.com/abu_fatih/Modelkm.html

https://meriaoctavianti.wordpress.com/2010/06/25/komunikasi-suami-istri-usaha-memahamikehidupan-bersama-pendahuluan/

http://pengertian-pengertian-info.blogspot.co.id/2015/05

http://www.quran30.net/2012/08/surat-ar-ruum-ayat-1-60.html

http://id.wikipedia.org

http://cbdotnet.blogspot.com/2009/02/pandangan-kaluarga-menurut-

islam.htmlhttp://blog.re.or.id/konsep-keluarga-sakinah-dalam-pandangan

islam.htm

http://blog.re.or.id/keluarga-dalam-pandangan-islam.htm

https://ajirudin.wordpress.com/2011/09/18/makalah-pengadilan-agama-sebagai-pengadilan-

keluarga/

http://en.wikipedia.org/wiki/Johari_window 